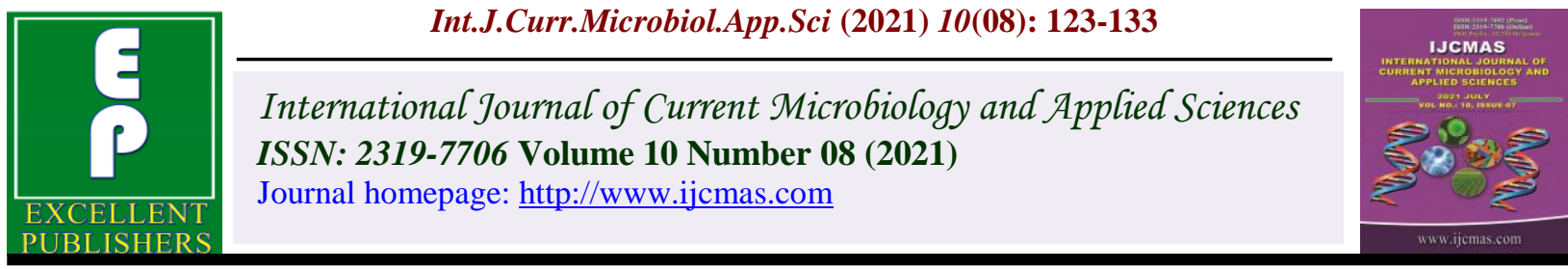

\title{
Estimation of Genetic Variability and Divergence for Fruit Yield and Yield Attributing Traits in Salad Cucumber (Cucumis sativus L.) in Southern Districts of Tamil Nadu
}

\author{
M. I. Manivannan ${ }^{1}$, R. Arulmozhiyan², J. Prem Joshua ${ }^{3}$ and R. Suresh ${ }^{4}$ \\ ${ }^{1}$ Department of Horticulture, Horticultural Research Station, Kodaikanal-624 103, India \\ ${ }^{2}$ Department of Horticulture, Agricultural College \& Research Institute \\ Killikulam-628252, India \\ ${ }^{3}$ Department of Post - Harvest Technology, Horticultural College \& Research Institute, \\ Periyakulam, India \\ ${ }^{4}$ ICAR - NAHEP - TNAU - IDP DABD, TNAU, Coimbatore -3, India \\ *Corresponding author
}

\section{A B S T R A C T}

Keywords

Cucumber, Genetic Advance,

Heritability Genetic

Divergence and

Mahalanobis D2

Cluster composition

Article Info

Accepted:

12 July 2021

Available Online:

10 August 2021
Twenty four diverse genotypes of cucumber collected from different indigenous sources were planted in randomized complete block design, for three consecutive seasons during Rabi for the years 2016, 2017 and 2018 and were assessed on pooled analysis basis to know the nature and magnitude of variability and genetic divergence for different horticultural traits. The genotype KCS 7 gave maximum mean value for number of fruits per plant, yield per vine and yield per hectare. High phenotypic coefficient of variability (PCV), genotypic coefficient of variability (GCV) and heritability estimates coupled with high genetic gain were observed for node at which first female flower appeared, number of fruits per plant, yield per vine and yield per hectare indicated the existence of wide range of variations and offers better scope for improvement through selection. The genotypes were grouped into 7 clusters and the highest (35.48) inter cluster distance was recorded between cluster III and VII. The diverse genotypes characterized by maximum inter cluster distance will differ in phenotypic performance and therefore, selection of divergent parents should be based on these cluster distances to obtain favorable hybrids and transgressive segregants in cucumber.

\section{Introduction}

Cucumber (Cucumis sativus L.) is one of the most important cucurbitaceous vegetable crops grown extensively in tropical and subtropical parts of the country. It is considered as $4^{\text {th }}$ most important vegetable crop after tomato, cabbage and onion (Tatlioglu, 1993). Cucumber is a thermophilic and frost susceptible crop species, growing best at a temperature above $20^{\circ} \mathrm{C}$. It is grown for its tender fruits, which are consumed either raw 
as salad, cooked as vegetable or as pickling cucumber in its immature stage. It is a rich source of vitamin B and C, carbohydrates, $\mathrm{Ca}$ and $\mathrm{P}$ (Yawalkar, 1985). In spite of being native of Indian sub-continent and endowed with enormous variability and genetic divergence, salad cucumber remains underutilized in terms of its economic potential and unexploited from breeding point of view. So, there is a great need of screening cucumber germplasm to select elite genotypes with improved quality and higher yield for direct selection or using as a parent in hybridization programme. Planning and execution of breeding programme for improvement of quantitative attributes depends, to a great extent, upon magnitude of genetic variability. The genotypic and phenotypic coefficients of variability are helpful in exploring the nature of variability in the breeding populations, whereas estimates of heritability provides index of transmissibility of characters. Hence, on the basis of these traits, suitable selection strategy can be formulated for higher yield in salad cucumber. Information on genetic diversity is used to identify the promising diverse genotypes, which may be used in further breeding programme. Therefore, with this backdrop, the present study was undertaken for three consecutive years to estimate the extent of variability, heritability, coefficients of variation, genetic advance and genetic divergence in twenty four diverse genotypes of cucumber.

\section{Materials and Methods}

\section{Experimental Site and Environment}

The present investigation was carried out during Rabi, 2016, 2017 and 2018 at Agricultural College \& Research Institute, Killikulam, Thoothukudi district, Tamil Nadu Agricultural University, Tamil Nadu. This location is at an elevation of $40 \mathrm{~m}$ (131.2 feet) above mean sea level lying between the $8^{\circ} 46$ $\mathrm{N}$ latitude and $77^{\circ} 42 \mathrm{E}$ longitudes. The mean annual rainfall of the farm is $736.7 \mathrm{~mm}$ which is being received in 40 rainy days. The maximum and minimum temperatures ranged from $39^{\circ} \mathrm{C}$ and $20^{\circ} \mathrm{C}$ to $22^{\circ} \mathrm{C}$, respectively. The relative humidity during the period of crop growth ranged between $42 \%$ to $98.71 \%$.

\section{Experimental Material, Layout and Observations}

The present investigation aimed with the study of genetic variability and divergence using twenty four germplasm lines collected from different sources viz., Assam Agricultural University, Jorhat and Kerala Agricultural University, Vellayani and also through intensive surveys made at Thoothukudi, Virudhunagar, Tenkasi and Tirunelveli districts in places like Radhapuram, Sattur, Sivakasi, Kallipatti, Surandai,Mecheri, Vembakottai, Pavoorchatram, Chinakollanpatti, Periyakollanpatti, Erukanpatti, Yelayirampannai, Aalampalayam, Thaiyalpatti, Tenkasi, Nanguneri, Kuruvikulam, Aalantha, Manathi, Villikury and Karungulam. The field experiment was conducted at Department of Horticulture at Agricultural College and Research Institute, Killikulam during rabi season for three consecutive years 2016, 2017 and 2018. A set of twenty four genotypes of cucumber were evaluated in Randomized Block Design (RBD) with three replications. In each replication, each genotype was grown in a single row of $6 \mathrm{~m}$ length with a spacing of 75 $\mathrm{x} 60 \mathrm{~cm}$ accommodating 10 plants in a replication for all the experiments. Standard cultural practices recommended in the Package of Practices for Vegetable Crops, were followed to ensure a healthy crop stand (Veeraragavathatham, 1998). Observations were recorded on five randomly selected plants in each replication for ten quantitative characters viz., plant height $(\mathrm{cm})$, number of 
primary branches per vine, days to $50 \%$ flowering, node at which first female flower appeared, fruit length $(\mathrm{cm})$, fruit circumference $(\mathrm{cm})$, number of fruits per plant, fruit weight $(\mathrm{g})$, yield per plant $(\mathrm{kg})$ and yield per hectare $(\mathrm{t})$. Colour of fruits was observed visually after harvesting with the help of colour chart of Royal Horticultural Society, London.

\section{Statistical Analysis}

The pooled data obtained for three consecutive years were subjected to analysis of variance as per procedure described by Gomez and Gomez (1983). The genotypic and phenotypic coefficients of variation were calculated as per formulae given by Burton and De-Vane (1953). Heritability and genetic advance were calculated according to Allard (1960) and genetic gain was estimated as per the method given by Johanson et al., (1955). Multivariate analysis was done utilizing Mahalanobis D2 statistics and genotypes were grouped into four different clusters following Tochers method as described by Rao (1952).

\section{Results and Discussion}

\section{Variability studies}

\section{Analysis of Variance}

Genetic variability is the basic need for a plant breeder to initiate any breeding programme. Genetic improvement can be brought about by manipulating the genetic makeup of the plant for desirable characters or to remove the undesirable genes which retard, or inhibit, certain pathways. Analysis of variance (Table 2) indicated significant differences among the genotypes for all the characters under study. These differences indicated the presence of variability in the available germplasm and offers opportunity for improvement in yield and quality traits of cucumber.

\section{Mean Performance of Genotypes}

Genetic variability is the basic need for a plant breeder to initiate any breeding programme. Among the horticultural traits, comparatively wide range was observed for morphological characters vine length $(179.84-294.28 \mathrm{~cm})$ and number of branches (2.33-6.42). Similarly, for days to first female flower (28.17-52.55) and node at which first female flower appeared (7.00-20.74), which determine the earliness of a variety (Table 3). Fruit length, circumference and weight are the major yield contributing traits, wide variations were observed with respect to these traits (17.23$23.88 \mathrm{~cm}, 9.27-14.83 \mathrm{~cm}, 135.99-199.02 \mathrm{~g}$, respectively). Tremendous variations with respect to number of marketable fruits per plant (4.67-12.54), yield per vine (0.88$2.21 \mathrm{~kg})$ and yield per hectare $(3.89-9.82 \mathrm{t})$ were obtained. The genotype KCS 7was found highest in yield (9.82t/ha) among all which was followed by four other genotypes namely KCS9, KCS8, KCS14 and KCS6. Wide variations with respect to various quantitative characters were also reported by Munshi et al., (2007), Kumar et al., (2008), Hanchinamani et al., (2008) and Yogesh et al., (2009) in cucumber. All the genotypes under study also showed wide variations for fruit colour (green, light green, dark green and white), which decides the consumer's preference. Majority of the genotypes including both the check cultivars had light green coloured fruits, which are in general preferred by consumers. Similar results have also been reported by Verma (2003) and Kumar (2006) for these characters.

\section{Parameters of Variability}

\section{Coefficients of Variability}

The estimates of phenotypic and genotypic coefficients of variability gave a clear picture of amount of variations presents in the available germplasm (Table 4). For all the 
characters studied, phenotypic coefficients of variability were higher in magnitude than genotypic coefficients of variability, though difference was not much in all the cases. Thus, showing that these traits are not much influenced by environmental factors. Hence, selection based on phenotypic performance will be more reliable. Coefficients of variability varied in magnitude from character to character, indicating that there was a great diversity in the experimental material used. The genotypic coefficients of variability (GCV) were high for node at which first female flower appeared, number of fruits/plant, yield per vine and yield per hectare. This reflects greater genetic variability among the genotypes for these characters for making further improvement by selection. Whereas, moderate GCV were recorded for number of primary branches, plant height and days to first female flower production. For, circumference of fruit, length of fruit and fruit weight GCV were low. Similar results had also been reported by Yogesh et al., (2009).

\section{Heritability and Genetic gain}

The estimates of heritability were found high for the characters viz. plant height, fruit weight, number of fruits per plant, yield per plant, yield per hectare wherein it was moderate for node at which first female flower appeared, circumference of fruit, days to first female flower production and length of fruit and low for number of primary branches (Table 4). Kumar et al., (2008) reported high heritability estimates for fruit yield per plant and moderate heritability for node number bearing first female flower. Similarly, high heritability was reported by Sandeep Kumar et al., (2013) and Yogesh et al., (2009) for fruit weight at edible maturity and fruit yield per plant and moderate heritability was found for node number bearing first female flower. High heritability estimates for fruit weight and fruit yield per plant were also reported by Singh
(1997) and Munshi et al., (2007). In the light of results obtained in the present studies, it is concluded that selection can be performed based on phenotypic performance for highly heritable characters viz. average fruit weight and yield per plant.

Genetic gain (expressed as per cent of population mean) was low to high in nature for different characters. It was found high for node at which first female flower appeared and number of fruits per plant. Moderate genetic gain was observed for yield per plant, yield per hectare, number of primary branches and plant height, whereas it was recorded low for days to first female flower production, circumference of fruit, weight of fruit and length of fruit. These findings are in line with Kumar et al., (2008) and Yogesh et al., (2009).

High heritability estimates coupled with high genetic gain were observed for plant height, node at which first female flower appeared, number of fruits per plant, yield per vine and yield per hectare which indicated that these characters are under additive gene effects and these characters are more reliable for effective selection (Panse, 1957). Similar results for fruit yield per plant have been reported by Singh (1997). High heritability coupled with moderate genetic gain was observed for days to first female flower appear, fruit length, fruit circumference and average fruit weight, indicated that these characters are under nonadditive gene effects and selection for these characters will be less effective.

Such traits are more under the influence of environment and do not respond to selection. Similar results were also reported by Sandeep Kumar et al., (2013), Kumar et al., (2008) and Yogesh et al., (2009).

\section{Genetic Divergence Studies}

Cluster composition after computing $\mathrm{D}^{2}$ 
values for all the possible pairs, 24 genotypes were grouped into 7 clusters, which indicated a large genetic diversity (Table 5). Maximum number of genotypes was accommodated in clusters II (7) followed by cluster III with 6 , cluster V and cluster VI with 3 genotypes, cluster I and cluster IV with 2 genotypes and cluster-VII with 1 genotype, respectively. The resultant seven clusters showed considerable genetic diversity. Genotypes from different geographical regions were grouped in the same cluster indicating no relationship between geographic distribution and genetic divergence, while genotypes collected from same location were grouped into different clusters, showing great genetic diversity. Similar results were also obtained by Rao et al., (2003), Khan (2006) and Kabir et al., (2009). Intra-cluster distance revealed that, cluster VI showed maximum intra-cluster distance (14.75) followed by cluster II (14.62), cluster V (14.48), cluster III (12.96), cluster IV(7.80) and cluster I with minimum intracluster distance (3.09), respectively. Based on distance between clusters, i.e., inter-cluster distance, the maximum divergence was observed between cluster III and VII (35.48) followed by divergence between cluster VI and VII (33.27) and the lowest (10.35) was recorded between cluster I and VI.

Table.1 List of cucumber genotypes studied along with their sources

\begin{tabular}{|c|c|}
\hline Accession No. & Place of collection \\
\hline KCS 1 & Radhapuram \\
\hline KCS 2 & Vellayani \\
\hline KCS 3 & Assam Agri University \\
\hline KCS 4 & Sattur \\
\hline KCS 5 & Radhapuram \\
\hline KCS 6 & Sivakasi \\
\hline KCS 7 & Kallipatti \\
\hline KCS 8 & Surandai \\
\hline KCS 9 & Mecheri \\
\hline KCS 10 & Vembakottai \\
\hline KCS 11 & Pavoorchatram \\
\hline KCS 12 & Chinakollanpatti \\
\hline KCS 13 & Periyakollanpatti \\
\hline KCS 14 & Erukanpatti \\
\hline KCS 15 & Yelayirampannai \\
\hline KCS 16 & Aalampalayam \\
\hline KCS 17 & Thaiyalpatti \\
\hline KCS 18 & Tenkasi \\
\hline KCS 19 & Nanguneri \\
\hline KCS 20 & Kuruvikulam \\
\hline KCS 21 & Aalantha \\
\hline KCS 22 & Manathi \\
\hline KCS 23 & Villikury \\
\hline KCS 24 & Karungulam \\
\hline
\end{tabular}


Table.2 Analysis of variance for different horticultural traits in cucumber

\begin{tabular}{|c|c|c|c|c|c|c|c|c|c|c|c|}
\hline Variables & $\begin{array}{l}\text { Degrees } \\
\text { of } \\
\text { freedom }\end{array}$ & $\begin{array}{c}\text { Vine } \\
\text { length } \\
\text { (cm) }\end{array}$ & $\begin{array}{c}\text { No. of } \\
\text { primary } \\
\text { branches }\end{array}$ & $\begin{array}{l}\text { Days to first } \\
\text { female flower } \\
\text { production }\end{array}$ & $\begin{array}{l}\text { Node at which } \\
\text { first female } \\
\text { flower appeared }\end{array}$ & $\begin{array}{l}\text { Lengt } \\
\text { h of } \\
\text { fruit } \\
(\mathrm{cm})\end{array}$ & $\begin{array}{l}\text { Circumfe } \\
\text { rence of } \\
\text { fruit } \\
(\mathrm{cm})\end{array}$ & $\begin{array}{c}\text { No. of } \\
\text { fruits/ } \\
\text { plant }\end{array}$ & $\begin{array}{c}\text { Fruit } \\
\text { weight } \\
\text { (g) }\end{array}$ & $\begin{array}{l}\text { Yield/ } \\
\text { vine } \\
(\mathrm{kg})\end{array}$ & $\begin{array}{l}\text { Yield } \\
\text { (t/ha) }\end{array}$ \\
\hline Year & 2 & $\begin{array}{c}1034.0 \\
2\end{array}$ & 0.37 & 21.04 & 10.73 & 8.66 & 3.85 & 5.81 & 239.70 & 0.26 & 5.18 \\
\hline $\begin{array}{l}\text { Replicatio } \\
\text { n with in } \\
\text { year }\end{array}$ & 6 & 39.92 & 0.01 & 0.85 & 0.23 & 0.07 & 0.09 & 0.05 & 5.63 & 0.00 & 0.03 \\
\hline $\begin{array}{c}\text { Genotype } \\
\text { S }\end{array}$ & 23 & $\begin{array}{c}11845 \\
59\end{array}$ & 6.42 & 268.00 & 112.91 & 33.75 & 14.80 & 40.47 & $\begin{array}{c}2188.8 \\
9\end{array}$ & 1.11 & 21.86 \\
\hline $\begin{array}{c}\text { Year:Gen } \\
\text { otypes }\end{array}$ & 46 & 28.49 & 0.53 & 7.56 & 2.85 & 0.99 & 0.40 & 0.44 & 17.51 & 0.02 & 0.30 \\
\hline $\begin{array}{l}\text { Pooled } \\
\text { Error }\end{array}$ & 138 & 32.60 & 0.01 & 0.95 & 0.12 & 0.33 & 0.09 & 0.06 & 18.24 & 0.00 & 0.04 \\
\hline Total & 215 & & & & & & & & & & \\
\hline
\end{tabular}

Table.3 Mean performance of cucumber genotypes for different horticultural traits

\begin{tabular}{|c|c|c|c|c|c|c|c|c|c|c|}
\hline $\begin{array}{l}\text { Accessi } \\
\text { ons }\end{array}$ & $\begin{array}{c}\text { Plant } \\
\text { Height }\end{array}$ & $\begin{array}{c}\text { No. of } \\
\text { primary } \\
\text { branches }\end{array}$ & $\begin{array}{l}\text { Days to first female } \\
\text { flower production }\end{array}$ & $\begin{array}{c}\text { Node at which first } \\
\text { female flower appeared }\end{array}$ & $\begin{array}{c}\text { Length } \\
\text { of fruit } \\
\text { (cm) }\end{array}$ & $\begin{array}{l}\text { Circumfere } \\
\text { nce of fruit } \\
\text { (cm) }\end{array}$ & $\begin{array}{c}\text { No. of } \\
\text { fruits/pla } \\
\text { nt }\end{array}$ & $\begin{array}{c}\text { Fruit } \\
\text { weight } \\
\text { (g) }\end{array}$ & $\begin{array}{l}\text { Yield/vi } \\
\text { ne }(\mathbf{k g})\end{array}$ & $\begin{array}{l}\text { Yield } \\
\text { (t/ha) }\end{array}$ \\
\hline KCS 1 & 261.09 & 3.23 & 32.32 & 11.44 & 17.65 & 11.36 & 10.33 & 151.35 & 1.56 & 6.95 \\
\hline KCS 2 & 230.55 & 5.03 & 41.00 & 11.15 & 19.65 & 11.17 & 10.67 & 163.79 & 1.75 & 7.76 \\
\hline KCS 3 & 235.17 & 3.73 & 33.33 & 12.33 & 20.53 & 11.00 & 9.50 & 167.77 & 1.59 & 7.09 \\
\hline KCS 4 & 285.26 & 5.02 & 52.55 & 13.78 & 21.41 & 14.03 & 8.08 & 193.44 & 1.56 & 6.95 \\
\hline KCS 5 & 291.80 & 3.73 & 39.67 & 15.72 & 21.40 & 14.83 & 6.58 & 199.02 & 1.31 & 5.83 \\
\hline KCS 6 & 194.57 & 4.49 & 29.44 & 11.17 & 17.23 & 12.20 & 10.75 & 166.71 & 1.79 & 7.97 \\
\hline KCS 7 & 205.39 & 6.42 & 28.17 & 7.00 & 18.54 & 10.56 & 12.54 & 176.18 & 2.21 & 9.82 \\
\hline KCS 8 & 249.18 & 4.52 & 37.58 & 8.30 & 20.46 & 11.52 & 11.15 & 176.00 & 1.96 & 8.72 \\
\hline
\end{tabular}


Int.J.Curr.Microbiol.App.Sci (2021) 10(08): 123-133

\begin{tabular}{|c|c|c|c|c|c|c|c|c|c|c|}
\hline KCS 9 & 260.58 & 4.53 & 39.00 & 9.17 & 20.95 & 11.77 & 11.42 & 178.00 & 2.03 & 9.04 \\
\hline KCS 10 & 200.81 & 4.52 & 43.44 & 12.55 & 22.87 & 12.65 & 9.33 & 193.98 & 1.81 & 8.05 \\
\hline KCS 11 & 208.75 & 5.38 & 35.78 & 12.12 & 20.21 & 10.19 & 9.67 & 177.37 & 1.71 & 7.62 \\
\hline KCS 12 & 288.44 & 4.20 & 37.86 & 11.54 & 19.40 & 9.27 & 9.92 & 135.99 & 1.35 & 5.99 \\
\hline KCS 13 & 200.94 & 3.55 & 41.00 & 13.05 & 18.28 & 10.12 & 8.67 & 146.58 & 1.27 & 5.65 \\
\hline KCS 14 & 179.84 & 4.22 & 40.22 & 11.08 & 23.63 & 12.37 & 10.50 & 184.74 & 1.94 & 8.63 \\
\hline KCS 15 & 221.57 & 3.98 & 38.73 & 12.52 & 22.83 & 12.31 & 9.78 & 181.66 & 1.78 & 7.90 \\
\hline KCS 16 & 215.53 & 4.28 & 40.68 & 13.42 & 23.48 & 9.74 & 9.33 & 171.23 & 1.60 & 7.11 \\
\hline KCS 17 & 211.12 & 4.49 & 36.67 & 14.75 & 22.77 & 11.75 & 7.00 & 183.10 & 1.28 & 5.70 \\
\hline KCS 18 & 241.44 & 5.14 & 31.10 & 12.65 & 19.61 & 12.24 & 9.75 & 176.84 & 1.72 & 7.66 \\
\hline KCS 19 & 278.53 & 3.80 & 31.07 & 13.11 & 20.92 & 12.84 & 9.67 & 180.78 & 1.75 & 7.77 \\
\hline KCS 20 & 244.69 & 3.26 & 39.67 & 9.81 & 19.12 & 10.53 & 11.67 & 148.64 & 1.74 & 7.71 \\
\hline KCS 21 & 294.28 & 4.19 & 37.94 & 20.74 & 20.16 & 11.91 & 5.08 & 176.02 & 0.90 & 3.98 \\
\hline KCS 22 & 222.06 & 2.33 & 28.61 & 15.89 & 21.79 & 11.12 & 6.92 & 178.54 & 1.24 & 5.49 \\
\hline KCS 23 & 190.53 & 3.50 & 33.83 & 19.39 & 23.01 & 12.12 & 5.67 & 182.32 & 1.03 & 4.59 \\
\hline KCS 24 & 182.03 & 3.51 & 37.11 & 21.28 & 23.88 & 12.37 & 4.67 & 187.90 & 0.88 & 3.89 \\
\hline Mean & 233.09 & 4.21 & 36.95 & 13.08 & 20.82 & 11.66 & 9.11 & 174.08 & 1.57 & 6.99 \\
\hline SE d & 5.10 & 0.09 & 0.79 & 0.28 & 0.44 & 0.24 & 0.19 & 4.11 & 0.04 & 0.16 \\
\hline $\begin{array}{c}\text { CD } \\
(p=0.05 \\
\%)\end{array}$ & 10.93 & 0.17 & 1.56 & 0.56 & 0.87 & 0.47 & 0.38 & 8.81 & 0.07 & 0.32 \\
\hline CV (\%) & 5.25 & 1.98 & 1.98 & 1.98 & 1.98 & 1.98 & 1.98 & 5.25 & 1.98 & 1.98 \\
\hline
\end{tabular}


Table.4 Estimates of phenotypic and genotypic coefficients of variability, heritabilityand genetic advance as percent of mean for different horticultural traits

\begin{tabular}{|c|c|c|c|c|c|}
\hline S.No & Parameters & \multicolumn{2}{|c|}{$\begin{array}{c}\text { Coefficients of } \\
\text { variability (\%) }\end{array}$} & $\begin{array}{c}\text { Heritability } \\
\mathbf{( \% )}\end{array}$ & $\begin{array}{c}\text { Genetic } \\
\text { advance (\%) }\end{array}$ \\
\cline { 2 - 4 } & & Phenotypic & Genotypic & & \\
\hline $\mathbf{1 .}$ & Plant Height & 15.60 & 15.55 & 99.28 & 31.91 \\
\hline $\mathbf{2 .}$ & No. of primary branches & 21.65 & 19.22 & 78.83 & 35.16 \\
\hline $\mathbf{3 .}$ & Days to first female flower appear & 15.18 & 14.56 & 91.98 & 28.77 \\
\hline $\mathbf{4 .}$ & Node at which first female flower appeared & 27.75 & 26.73 & 92.79 & 53.04 \\
\hline $\mathbf{5 .}$ & Length of fruit(cm) & 9.57 & 9.16 & 91.64 & 18.06 \\
\hline $\mathbf{6 .}$ & Circumference of fruit(cm) & 11.28 & 10.85 & 92.37 & 21.47 \\
\hline $\mathbf{7 .}$ & No. of fruits/plant & 23.53 & 23.15 & 96.79 & 46.92 \\
\hline $\mathbf{8 .}$ & Fruit weight (g) & 9.03 & 8.92 & 97.64 & 18.16 \\
\hline $\mathbf{9 .}$ & Yield/vine (kg) & 22.59 & 22.14 & 96.02 & 44.68 \\
\hline $\mathbf{1 0 .}$ & Yield (t/ha) & 22.59 & 22.13 & 96.01 & 44.67 \\
\hline
\end{tabular}

Table.5 Clustering pattern and average intra and inter cluster distance (D2) of 24 genotypes of cucumber

\begin{tabular}{|c|c|c|c|c|c|c|c|}
\hline Cluster & I & II & III & IV & V & VI & VII \\
\hline I & 3.09 & 17.90 & 12.28 & 24.46 & 12.95 & 10.35 & 28.56 \\
\hline II & & 14.62 & 24.86 & 14.23 & 16.41 & 22.96 & 18.37 \\
\hline III & & & 12.96 & 31.71 & 17.30 & 12.82 & 35.48 \\
\hline IV & & & & 7.80 & 21.30 & 29.38 & 10.97 \\
\hline V & & & & & 14.48 & 16.58 & 25.46 \\
\hline VI & & & & & & 14.75 & 33.27 \\
\hline VII & & & & & & & 0.00 \\
\hline
\end{tabular}

Table.6 Distribution of 24 cucumber genotypes in different clusters

\begin{tabular}{|c|c|c|c|}
\hline S.No & $\begin{array}{c}\text { Name of } \\
\text { the cluster }\end{array}$ & $\begin{array}{c}\text { No. of } \\
\text { genotypes }\end{array}$ & Name of genotypes \\
\hline $\mathbf{1}$ & I & 2 & KCS 15 and KCS 16 \\
\hline $\mathbf{2}$ & II & 7 & KCS 1,KCS 2, KCS 3, KCS 4, KCS 5, KCS 8 and KCS 9 \\
\hline $\mathbf{3}$ & III & 7 & KCS 6, KCS 7, KCS 10, KCS 11, KCS 23 and KCS 24 \\
\hline $\mathbf{4}$ & IV & 2 & KCS 12 and KCS 19 \\
\hline $\mathbf{5}$ & V & 3 & KCS 13, KCS 18 and KCS 20 \\
\hline $\mathbf{6}$ & VI & 3 & KCS 14, KCS 17 and KCS 22 \\
\hline $\mathbf{7}$ & VII & 1 & KCS 21 \\
\hline
\end{tabular}


Table.7 Cluster means for different characters among 24 genotypes of cucumber

\begin{tabular}{|c|c|c|c|c|c|c|c|c|c|c|}
\hline Cluster & $\begin{array}{c}\text { Vine } \\
\text { length } \\
\text { (cm) }\end{array}$ & $\begin{array}{c}\begin{array}{c}\text { Number } \\
\text { of } \\
\text { primary } \\
\text { branches }\end{array}\end{array}$ & $\begin{array}{c}\text { Days to } \\
\text { first } \\
\text { female } \\
\text { flowering }\end{array}$ & $\begin{array}{c}\text { Node at } \\
\text { which } \\
\text { first } \\
\text { female } \\
\text { flower } \\
\text { appear }\end{array}$ & $\begin{array}{c}\text { Fruit } \\
\text { length } \\
(\mathrm{cm})\end{array}$ & $\begin{array}{c}\text { Fruit } \\
\text { circumference } \\
(\mathbf{c m})\end{array}$ & $\begin{array}{c}\text { Number } \\
\text { of fruits } \\
\text { per } \\
\text { plant }\end{array}$ & $\begin{array}{c}\text { Fruit } \\
\text { weight } \\
\text { (g) }\end{array}$ & $\begin{array}{l}\text { Yield } \\
\text { per } \\
\text { vine } \\
(\mathrm{kg})\end{array}$ & $\begin{array}{l}\text { Yield } \\
\text { (t/ha) }\end{array}$ \\
\hline I & 218.55 & 4.13 & 39.71 & 12.97 & 23.16 & 12.34 & 6.81 & 62.79 & 118.71 & 1.33 \\
\hline II & 259.09 & 4.26 & 39.35 & 11.70 & 20.29 & 11.89 & 6.21 & 51.86 & 117.79 & 1.43 \\
\hline III & 197.01 & 4.64 & 34.63 & 13.92 & 20.96 & 12.14 & 5.78 & 63.01 & 120.48 & 1.15 \\
\hline IV & 283.49 & 4.00 & 34.47 & 12.33 & 20.16 & 11.10 & 6.54 & 61.92 & 107.42 & 1.15 \\
\hline V & 229.03 & 3.98 & 37.26 & 11.84 & 19.00 & 11.18 & 5.97 & 57.68 & 105.30 & 1.19 \\
\hline VI & 204.34 & 3.68 & 35.17 & 13.91 & 22.73 & 15.09 & 5.19 & 56.99 & 122.33 & 1.01 \\
\hline VII & 294.28 & 4.19 & 37.94 & 20.74 & 20.16 & 10.53 & 8.00 & 50.15 & 118.69 & 0.90 \\
\hline
\end{tabular}


Cluster means for crop improvement, intercrossing among genotypes with outstanding mean performance was suggested by Roy and Sharma (1996). The cluster means of the various horticultural traits are presented in Table 4. Moreover, for getting the reliable conformity on the basis of cluster means, cluster-VII exhibited higher means for vine length (294.28) and number of fruits per plant (8.00). Cluster-I gave maximum mean values for fruit length(23.16) wherein cluster II recorded lowest node at which first female flower appear(11.70), the highest (20.74) being recorded in cluster VII. Cluster II also exerted superiority for yield per hectare (1.43). Cluster VI recorded maximum mean values for yield per vine (122.33). Cluster IV exerted minimum values for days to first female flowering (34.47) wherein cluster I registered maximum values (39.71) for the same character. Cluster VI exerted superiority for the characters fruit circumference (15.09) and yield per vine (122.33). Cluster III registered higher means for the important yield attributing characters viz., number of primary branches (4.64) and fruit weight (63.01). Cluster V did not possess superiority for any character.

The genotypes having wide genetic base and desirable characteristics can be involved in intra-specific crosses which would lead to transmission of good genetic gain for various putative traits including yield for practical utility. Hence, crossing between the genotypes of maximum two clusters (II and III) appeared to be most promising to combine the desirable characters. Earlier workers like Kushwah et al., (2005) and Khan (2006) have also indicated the significance of genetic divergence. But, Mian and Bhal (1989) reported that parental clusters separated by medium D2 values had significant positive heterosis. Thus, heterosis could also be exploited by crossing between genotypes belonging to clusters with moderate diversity like genotypes of cluster IV and X, cluster VI $\& \mathrm{X}$ and $\mathrm{X} \& \mathrm{XI}$. They are likely to produce new recombinant with desired traits. Considering the magnitude of genetic distance and cluster means for different characters performance, the genotypeKCS-21 of cluster VII could be selected for vine length wherein KCS-24of cluster III could be selected for fruit length. The genotypes KCS-5 in cluster II and KCS-19 in cluster IV were promising for the characters fruit weight and fruit circumference, respectively. In cluster III, the genotypeKCS-7 could be selected for number of primary branches, days to first female flowering, node at which first female flower appeared, number of fruits per plant, yield per vine and yield per hectare if used in hybridization programme.

\section{References}

Allard, R. W. 1960. Principles of Plant Breeding. John Wiley and sons, New York. 485p.

Burton, G. W. and DeVane, E. H. 1953. Estimating heritability in tall fescue (Festuca arundiancea) from replicated clonal material. Agron. J. 45: 478-481.

Gomez, K. A. and Gomez, A. A. 1983. Statistical Procedures for Agricultural Research. John Wiley and Sons Inc., New York. 680p.

Hanchinamani, C. N.; Patil, M. G.; Dharmatti, P. R. and Mokashi, A. N. 2008. Studies on variability in cucumber (Cucumis sativus L.). Crop Res. 36(1\&3): 273-276.

Johanson, H. W.; Robinson, H. F. and Comstock, R. E. 1955. Estimates of genetic and environmental variability in soybean. Agron J. 47: 314-318.

Kabir, M. Y.; Khan, A. S. M. M. R. and Hassain, M. S. 2009. Genetic divergence in pointed gourd. J. Agric. Rural Dev. 7(1\&2): 87-92.

Khan, A. S. M. M. R. 2006. Study on genetic diversity and production technology of pointed gourd. Ph.D. Thesis, Bangladesh Agricultural University, Mymensingh, 
Bangladesh.

Kumar, A. 2006. Studies on heterosis and inheritance of resistance to fruit fly in cucumber (Cucumis sativus L.). Ph.D. Thesis, Department of Vegetable Science, Dr. Y. S. Parmar University of Horticulture and Forestry, Nauni, Solan, H.P.

Kumar, A.; Kumar, S. and Pal, A. K. 2008. Genetic variability and characters association for fruit yield and yield traits in cucumber. Indian J. Hort. 65(4): 423-428.

Kushwah, S.; Bandyopadhya, B. B. and Sharma, R. N. 2005. Genetic divergence in brinjal. Haryana J. Hort. Sci. 34(3\&4): 316-317.

Mahalanobis, P. C. 1936. On the generalized distance in statistics. Proceedings of National Academy of Science, India 2: 4955.

Mian, M. A. K. and Bhal, P. N. 1989. Genetic divergence and hybrid performance in chickpea. Indian J. Genet. 49(1): 119-129.

Munshi, A. D.; Panda, B.; Behera, T. K.; Kumar, R.; Bisht, I. S. and Behera, T. K. 2007. Genetic variability in Cucumis sativus var. hardwickii R. germplasm. Cucurbit Genet. Coop. 30: 5-10.

Panse, V. S. 1957. Genetics of quantitative characters in relation to plant breeding. Indian J. Genet. 17: 318-328.

Rao, E. S.; Verma, V. K. and Munshi, A. D. 2003. Breeding potential of cucumber (Cucumis sativus L.) genotypes using D2 analysis. Indian J. Hort. 60(1): 53-58.

Rao, R. 1952. Advanced statistical methods in biometrical research. John Wiley and Sons Inc., New York. 390p.
Roy, A. and Sharma, R. N. 1996. Multivariate analysis in chilli (Capsicum annum L.). Annals Agric. Res. 17(1): 30-32.

Sandeep Kumar, Dharminder Kumar, Ramesh Kumar, K S Thakur and Balbir Singh Dogra (2013). Estimation of Genetic Variability and Divergence for Fruit Yield and Quality Traits in Cucumber (Cucumis Sativus L.) in North-Western Himalayas. Universal Journal of Plant Sciences 1(2): 27-36.

Tatlioglu, T. 1993. Cucumber (Cucumis sativus L.) p. 197-233. In: Genetic Improvement of Vegetable Crops. Kalloo, G. and B. O. Beorgh (eds.). Pergamon Press, Oxford.

Veeraragavathatham, D., M. Jawaharlal and Seemanthini Ramadas. 1998. A Guide onVegetable culture. Tamil Nadu Agricultural University.

Verma, S. 2003. Genetic variability and correlation studies in cucumber (Cucumis sativus L.). M. Sc. Thesis, Department of Vegetable Science, Dr. Y. S. Parmar University of Horticulture and Forestry, Nauni, Solan, H.P.

Yawalkar, K. S. 1985. Vegetable Crops of India. Agri-Horticultural Publishing House, Nagpur. Yogesh, C.; Yadav, S. K.; Brijpal, B. and Dixit, S.K. 2009. Genetic variability, heritability and genetic advance for some traits in cucumber. Indian J. Hort. 66(4): 488-491.

Yogesh, C.; Yadav, S. K.; Brijpal, B. and Dixit, S. K. 2009. Genetic variability, heritability and genetic advance for some traits in cucumber. Indian J. Hort. 66(4): 488-491.

\section{How to cite this article:}

Manivannan, M. I., R. Arulmozhiyan, J. Prem Joshua and Suresh, R. 2021. Estimation of Genetic Variability and Divergence for Fruit Yield and Yield Attributing Traits in Salad Cucumber (Cucumis sativus L.) in Southern Districts of Tamil Nadu. Int.J.Curr.Microbiol.App.Sci. 10(08): 123-133. doi: https://doi.org/10.20546/ijcmas.2021.1008.016 